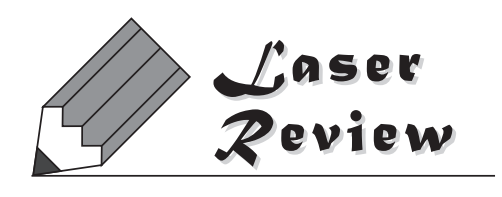

\title{
環境計測用衛星搭載レーザーレーダ(ライダー)技術
}

\author{
境澤 大亮 ${ }^{1}$, 中島 正勝 ${ }^{1}$, 田中 智章 ${ }^{2}$, 森野 勇 $^{2}$, 内野修 ${ }^{2}$ \\ 1宇宙航空研究開発機構（†305-8505 茨城県つくば市千現2-1-1） \\ ²⿴囗玉立環境研究所（テ305-8506 茨城県つくば市小野川16-2）
}

\section{Space-Borne Lidar Technology for Global Environmental Observation Research}

\author{
Daisuke SAKAIZAWA, ${ }^{1}$ Masakatsu NAKAJIMA, ${ }^{1}$ Tomoaki TANAKA, ${ }^{2}$ \\ Isamu MORINO, ${ }^{2}$ and Osamu UCHINO ${ }^{2}$ \\ ${ }^{1}$ Japan Aerospace Exploration Agency, 2-1-1 Sengen, Tsukuba-City, Ibaraki 305-8505 \\ ${ }^{2}$ National Institute of Environmental Studies, 16-2 Onogawa, Tsukuba-City, Ibaraki 305-8506
}

(Received September 3, 2010)

\begin{abstract}
Over the past decade, lidar (light detection and ranging) technologies for environmental study have advanced from ground-based to space-borne. The GLAS (the Geoscience Laser Altimeter System) and CALIPSO (the Cloud-Aerosol Lidar with Orthogonal Polarization) demonstrated lidar usability from space, both with the goal of measuring ice sheets, aerosols and clouds, and using those observationally derived data to improve climate modeling; for example, for better estimates of radiative forcing by aerosols. Subsequently, several studies have demonstrated the feasibility of using lidar systems to observe atmospheric winds and trace gases. The Japan Aerospace Exploration Agency (JAXA) has also initiated research and development to overcome the limitations of existing passive sounding concepts. This paper will introduce current and near-future space-borne lidar missions. In addition, the preliminary results of a demonstration flight test to evaluate the column-averaged $\mathrm{CO}_{2}$ density will be presented.
\end{abstract}

Key Words: Space-borne lidar, DIAL, IPDA, LAS, Carbon dioxide

\section{1.はじめに}

高分解能衛星画像や気象衛星, 地球観測衛星の商業利 用や数值予報モデルへのデータ同化利用 ${ }^{\dagger 1}$ を通じて各国 の地球観測衛星開発が盛んになっている. 背景の一つと して気候変動の将来予測やその検証があげられる。気候 変動に関する政府間パネル(IPCC)が示した放射収支の 導出には雲やエアロゾル, 微量気体等の観測值を用いた 数值モデルによる解析研究が大きな効果を発揮した。た だし各物理量が気候変動に及ぼす影響には未だ不確実性 があり，観測デー夕の高精度，高確度，高分解能化によ る低減が今後の課題である. 特に二酸化炭素 $\left(\mathrm{CO}_{2}\right)$ やメ タン $\left(\mathrm{CH}_{4}\right)$, エアロゾル等の自然起源および人為起源を 区別した生成消失要因の評価等，課題が多岐にわたる。 現在の観測研究は現場観測器を用いて航空機搭載, 地上 システムを含め高精度な值が得られるものの, 全球を補 う観測点を実現することが困難である。一方衛星軌道上
からの観測は地上観測で得られるデータと比較して精度 の点で劣るものの同一の観測器で全球を一様に評価でき ることが大きな利点である。これまで主要な衛星光学観 測は太陽光や地球の放射熱を光源とした受動型センサに よる2次元観測であるが，近年レーザーを光源とするラ イダーの衛星搭載システムの開発が活発化している.

ライダーはレーザーを用いたセンサであり，太陽光や 地球の放射熱を観測する従来の受動センサと比べて観測 量の3次元分布を精度良く取得できる。 ライダーの技術 開発はレーザーや光検出器，通信技術やデータ処理技術 の向上によって，過去10数年で地上観測, 航空機搭載を 経て衛星搭載を実現しデー夕利用に至る分野にまで大き く進展した.ライダーでは従来の受動型光学センサでは 得られない3次元分布や昼夜観測が可能である。本稿で はライダー計測技術の概要と現在進められている衛星搭 載ライダーの概要について紹介する.

†1 デー夕同化：数值天気予報や各種の最適化処理に用いられている技法．観測や実験デー夕を最適化理論を用いて取込み，モデル結 果を逐次修正する。観測データと数值モデルの双方から情報を取り出して, 統計的あるいは力学的に組合せて, 最適な条件や推定 を求める手法. 


\section{2. ライダーを用いた環境計測の意義}

エアロゾルや大気風，ならびに微量気体の観測を行う ライダーは，通常ナノ秒パルスレーザーを大気中へ照射 し, 大気分子や粒子による散乱光強度を測定する。衛星 観測ライダーとしてミー散乱ライダー, 高スペクトル分 解能ライダー (High Spectral Resolution Lidar: HSRL), ドップラー風ライダー (Doppler Wind Lidar: DWL), 差分 吸収ライダー (Differential Absorption lidar: DIAL)のシス テムが運用もしくは開発が進められている。ミー散乱ラ イダーは大気中のエアロゾルにより散乱されたレーザー 強度を測定する。得られた信号からエアロゾルの後方散 乱係数や消散係数 (光学的厚さ) といった物理量が得られ るが, 一波長での観測ではいくつかの仮定が必要とな る。一方, HSRLではこれらの仮定を置くことなく物理 量の測定が可能である ${ }^{1-3)}$. HSRLでは受光系に狭帯域の エタロンフィルタやヨウ素フィルタなど高精度な分光測 定を必要とするが粒子散乱 (ミー散乱) と分子散乱 (レイ リー散乱)を分離して検出・評価が可能である ${ }^{4)}$. エア ロゾルは大気微粒子として一括りとされるが, 粒子径は $10 \mathrm{~nm} \sim 10 \mu \mathrm{m}$ 程度と幅広く, 生成過程も多様であるた め気候変動予測では自然起源として海塩・土壤粒子, 人 為起源として硫酸塩, 炭素(ブラックカーボン)の4種類 の粒子を類型としている。エアロゾルはそれ自身が放射 収支に影響を与え，かつ雲の生成にも密接にかかわるた め, 複合的なメカニズム解明は重要課題である。しかし 時空間的に変動が大きく, 確定的な把握が非常に難しい ため衛星搭載ライダーによる継続的な大気エアロゾル観 測が重要となる。

DWLは大気分子や風とともに運動するエアロゾルの 散乱で生じるドップラー周波数を検出する。 $355 \mathrm{~nm}$ $532 \mathrm{~nm}$ の紫外〜可視域ではインコヒーレントシステム (Incoherent DWL: IDWL)，1.5〜2.0 umの短波長赤外では コヒーレントシステム (Coherent DWL: CDWL)が用いら れる ${ }^{5,6)}$. CDWLは航空機の運航に関わる晴天乱気流の検 知や, 夏季の東京都下で発生する急激な低気圧の発達を 事前に検出する試みに利用されている。IDWLは大気分 子からの散乱光も検出可能なため成層圈低層の風速測定 が可能である。ただし同じ条件下のシステム規模で比較 するとレーザーパルス単一ショットあたりの信号雑音比 でCDWLの方が有利となる. 数值気象予報モデルで利用 される風の観測デー夕は, 世界各地に点在する気象台で 実施されている気象ゾンデ(ヘリウムなどを充填した気 球に機材を取り付けて放球し気象デー夕の高度分布を取 得する観測器)や船舶, 航空機での観測データに依存し ており海洋上や未開発地域のデー夕，特に3次元データ が極端に乏しい，衛星搭載ライダーによる大気風の3次 元データはこういった数值天気予報の改善のみならず, 気候変動にかかる大気大循環の予測にも重要である.

DIALは少なくとも2つのレーザーを用いて $\mathrm{CO}_{2}$ や水蒸 気, オゾンといった微量気体濃度を取得できる。レー ザーは微量気体固有の吸収線に対して吸収量の強い波長 (オンライン)と弱い波長(オフライン)を利用し, 双方の
Table 1 Absorption wavelengths for atmospheric trace gases considered key indicators of climate change and absorption bands suitable for DIAL or LAS measurements.

\begin{tabular}{cc}
\hline Molecular & Absorption band \\
\hline $\mathrm{H}_{2} \mathrm{O}$ & $725-780 \mathrm{~nm}, 813-818 \mathrm{~nm}, 930-960 \mathrm{~nm}$ \\
\hline $\mathrm{O}_{3}$ & $280-300 \mathrm{~nm}$ \\
\hline $\mathrm{SO}_{2}$ & $300 \mathrm{~nm}+/-1 \mathrm{~nm}$ \\
\hline $\mathrm{CH}_{4}$ & $1670 \mathrm{~nm}, 3390 \mathrm{~nm}$ \\
\hline $\mathrm{CO}$ & $2320-2380 \mathrm{~nm}, 4550-4800 \mathrm{~nm}$ \\
\hline $\mathrm{NO}_{2}$ & $400-700 \mathrm{~nm}, 3400 \mathrm{~nm}$ \\
\hline $\mathrm{O}_{2}$ & $760 \mathrm{~nm}\left(\mathrm{O}_{2}-\mathrm{A}\right), 1270 \mathrm{~nm}$ \\
\hline
\end{tabular}

差分から光学的厚さが測定できる. この光学的厚さと気 象デー夕を用いて微量気体濃度が推定できる。 Table 1に これまで実施された地上, 航空機DIALの観測波長と衛 星からのDIAL観測で着目されている $\mathrm{O}_{2}, \mathrm{CO}, \mathrm{NO}_{2}$ 観測 に適したレーザー波長を示す ${ }^{7-13)}$. 周知のとおり, $\mathrm{CO}_{2}$ や $\mathrm{CH}_{4}$ といった微量気体は地球の放射収支に与える影響 が顕著なものとして着目されており，エアロゾルや雲同 様に観測デー夕の整備が求められている。微量気体の将 来予測や影響評価の不確実性を改善するため $\mathrm{CO}_{2}$ の場 合, 要求されている精度は全球平均濃度, $386.8 \mathrm{ppm}$ (2009年，世界気象機関)に対して1〜2 ppmである ${ }^{14,15)}$. 2009年1月には本格的な宇宙からの $\mathrm{CO}_{2}$ 観測を目的とし て温室効果ガス観測技術衛星GOSAT ${ }^{16)}$ (Greenhouse gases Observing SATellite) が全球観測を開始，2013年には OCO-2 (the Orbiting Carbon Observatory-2 by NASA) の打 ち上げが計画され2016年まで観測計画が策定されてい る。以降の継続観測システムにはこれらの後継機に加 え, レーザーを用いたDIALや長光路差分吸収ライダー (Integrated Path Differential Absorption lidar: IPDA-lidar), レーザー差分吸収分光計 (Laser differential absorption spectrometer: LAS）も議論されている。著者らは距離分 解能測定を行わずシステムと観測ターゲット間に存在す る微量気体の全量を測定するLASの開発を2005年から開 始した ${ }^{17)}$ 。受動型センサと比較してDIAL，LASによる 衛星軌道上からの観測は，1）シベリア森林帯等を含む冬 季高緯度帯で受動型のように光源の入射角に対して季節 依存性がない，2)昼夜にわたって同じ観測量で評価がで きる，3）視野が狭く(地上フットプリント $100 \mathrm{~m}$ 以下) 観 測要求達成に際しエアロゾルや雲の影響を受けにくい,

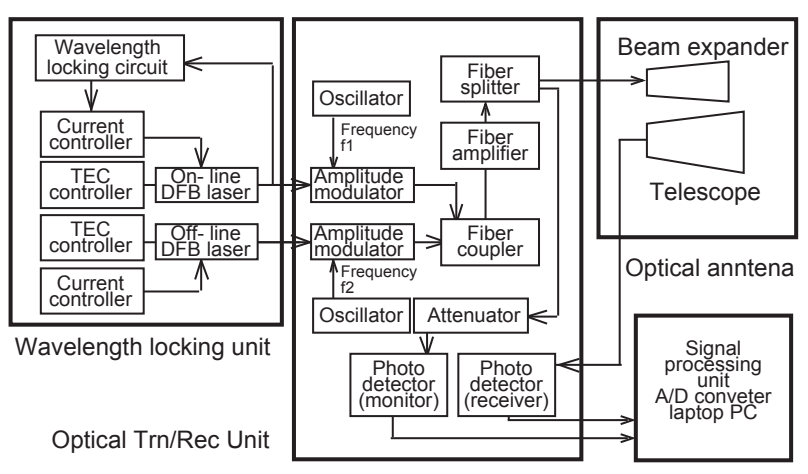

Fig. 1 Schematic diagram of LAS system for atmospheric $\mathrm{CO}_{2}$ sensing. 
4) 地表面反射率の変動にともなう観測精度への影響がな い, といった優位性を持つ. 我々はFig. 1のような構成 のプロトタイプを開発し地上及び航空機試験による実証 試験を行っている。このプロトタイプを用いた地上試験 ではランダム誤差 $0.5 \%(2 \mathrm{ppm})$ 以下が得られている ${ }^{18)}$. 衛星搭載用として他にNASA, ESAでも積極的に研究開 発が進められている19-21)

\section{3. 衛星搭載ライダーの現状}

宇宙からのライダー観測は1994年にNASAが実施した LITE (Lidar in-Space Technology Experiment) 計画から始ま る22)。この計画ではスペースシャトルにミー散乱ライ ダーを搭載し11日間の運用で宇宙からのライダー観測と その技術実証を達成した。ただしレーザー発振にはフ ラッシュランプ励起システムが利用されており, $3 \mathrm{~kW}$ におよぶ消費電力が必要なシステムであった。 その後 LD励起システムの改良に伴い250-300 W程度にまで改 善され，2003年にICESat (The Ice, Cloud and land Elevation SATellite ${ }^{23)}$ ，2006年にCALIPSO (The Cloud-Aerosol Lidar and Infrared Pathfinder Satellite Observations) ${ }^{24)}$ が打上げら れた。 ICESat搭載のGLAS (the Geoscience Laser Altimeter System) は高度計（送信レーザー：73 mJ-40 Hz/1064 nm, $36 \mathrm{~mJ}-40 \mathrm{~Hz} / 532 \mathrm{~nm}$, 水平分解能: $175 \mathrm{~m}$, 高さ精度 : $15 \mathrm{~cm}$ ), CALIPSO搭載のCALIOP (the Cloud-Aerosol Lidar with Orthogonal Polarization) はエアロゾル・絹雲観測器 としてNd:YAGレーザーの基本波 $(1064 \mathrm{~nm})$ と第二高調 波 $(532 \mathrm{~nm}$ ) 観測に使用している(送信レーザー： $110 \mathrm{~mJ}-20.2 \mathrm{~Hz} / 1064 \mathrm{~nm}, 532 \mathrm{~nm}$, 高度分解能: $30 \mathrm{~m}$, 水平分解能 : $333 \mathrm{~m}$ ). GLASでは初期にレーザーの不具 合が報告されたが運用調整により7年にわたるキャン ペーン観測を実施し，2010年2月まで運用を継続した。 CALIPSOはGLASにおけるレーザー不具合の対策を施し 2006年の打上げ以降, 設計寿命3年を超え2010年11月以 降も観測を継続しており，Fig. 2に示すようなエアロゾ ルの鉛直構造の観測やダストイベントの動体解析の検証 に利用されている。 また, ICESatでは他の衛星観測デー 夕と併用して全球の樹冠マップが作成されている ${ }^{25)}$. こ の樹冠マップは現場観測データや樹齢などを組合せて森 林の $\mathrm{CO}_{2}$ 吸収量推定に利用される. CALIPSOではエアロ ゾルに加え黄砂等の動態研究や大気輸送モデルの検証に 用いられている. IPCCの放射強制力の見積りにも用い られる全球エアロゾル気候モデルSPRINTARSへのデー 夕提供や数值モデルが示すデータの強力な検証手段とし て威力を発揮する $26-28)$.

2010年11月現在, 打上げに向けて開発中のライダー 搭載衛星はESA/JAXA/NICTの日欧共同プロジェクトで レーダ (Cloud Profiling Radar: CPR) とライダー (ATmopheric LIDar: ATLID) に加え受動光学センサをバランスよく搭 載したEarthCARE ${ }^{29,30)}$ ，大気風観測用のライダーでESA により開発が進められているADM-Aeolus ${ }^{31)}$ (the Atmospheric Dynamics Mission) である. EarthCAREは CALIPSOの後継として雲/放射相互作用, 熱帯降雨およ

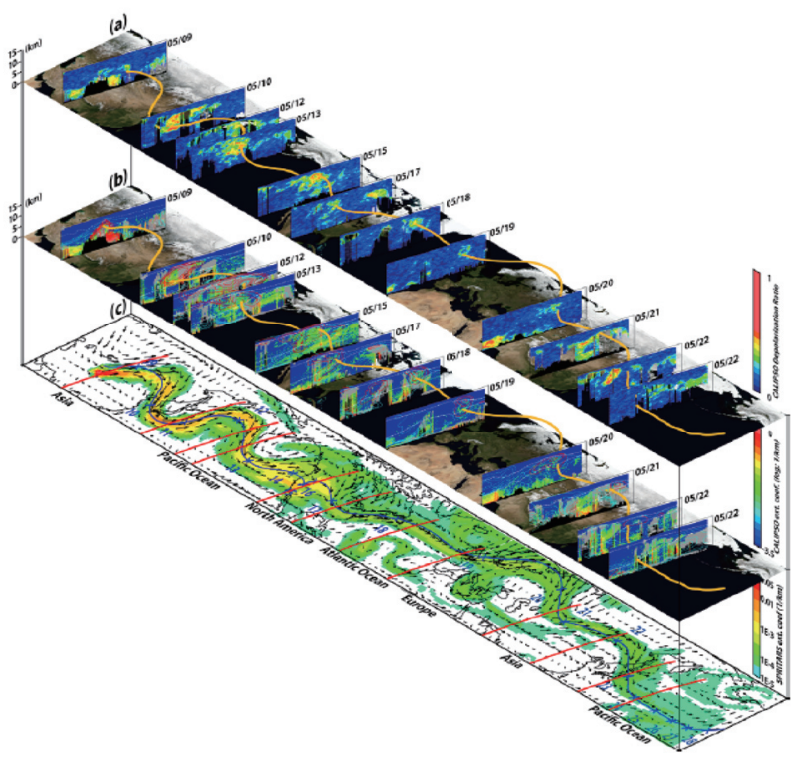

Fig. 2 Validation of aerosol transport model analysis using CALIPSO ${ }^{26)}$. This figure shows the Taklimakan dust journey during which Asian dust from the Taklimakan Desert travels around the world in 13 days. Vertical color images obtained from CALIOP observations: (a) depolarization ratio related to aerosol shape, [spherical (lower values) or non-spherical (higher value)], (b) dust extinction coefficients related to atmospheric transmittance, (c) analyzed trajectory of dust transport path [the same as the yellow line indicated in (a) and (b)]. (Reprinted by permission from Nature Geoscience Volume 2, No. 8, pp.529-596, supplementary data, Fig. S2, August 2009 Copyright: Macmillan Publishers Limited.).

び循環の量的研究を目的としている。またADMは世界 初の衛星搭載IDWLであり, 狭帯域光注入 (Injection seeding）により狭帯域化したNd:YAGの第三高調波 $(100 \mathrm{~mJ}-50 \mathrm{~Hz})$ とHSRLの特性を生かして対流圈から成 層圏に至る大気風の鉛直構造を計測する，得られた観測 データは事前に検討されたデータ同化により気象予報の 精度向上に向けた取組みが期待される ${ }^{32)}$.

\section{JAXAにおける取組と基盤技術への要求}

\section{1 航空機観測}

JAXAでは先に述べた $\mathrm{CO}_{2}$ 観測用LASのプロトタイプ を航空機に搭載し, $\mathrm{CO}_{2}$ 気柱量観測の実証試験を実施し た. LASシステムを航空機内に設置し, 光学空を通して レーザーを地表に向けて照射し地表面からの散乱光を観 測する。航空機試験は2010年2月と2009年8月の晴天時の 正午前後に観測した。全飛行経路はFig. 3が示すとおり 関東と北海道で実施した。一例として8月の観測につい て述べる。この観測では北海道帯広市近傍の牧草地で集 中的に観測した。得られた観測データの検証には航空機 外の空気 $\mathrm{CO}_{2}$ 濃度を直接測定したものを用いた。大気中 の $\mathrm{CO}_{2}$ 濃度は飛行高度7 kmから $0.5 \mathrm{~km}$ まで降下するスパ イラル観測で採取した。 


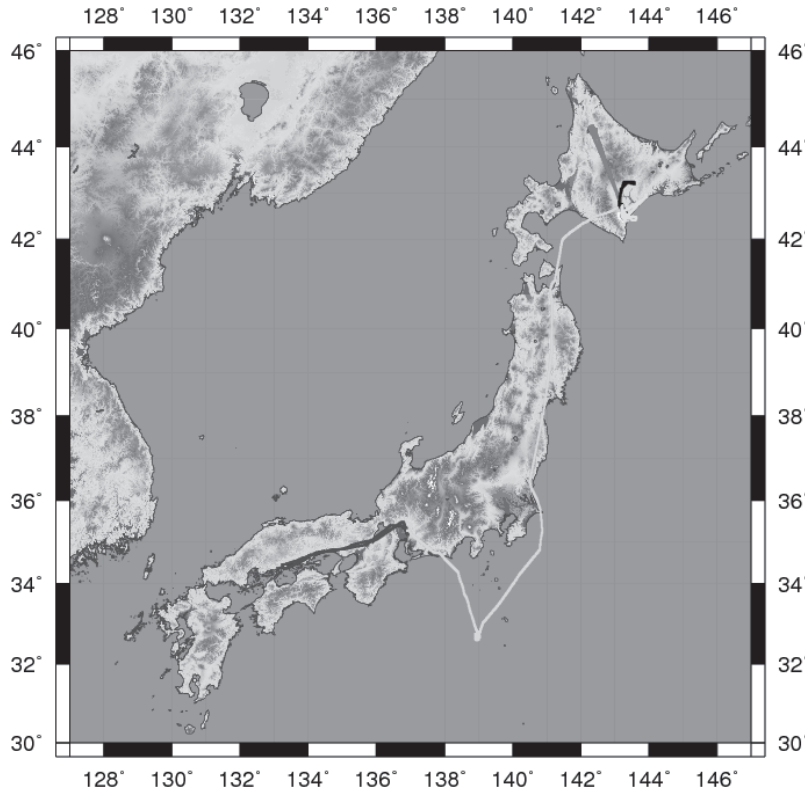

Fig. 3 Locations of flights of JAXA LAS system.

LASの光学的厚さとフラスコサンプリングで取得した $\mathrm{CO}_{2}$ 濃度から計算した光学的厚さをFig. 4に示す。図中 の点が平均值, エラーバーは光学的厚さ $(\Delta \tau)$ のばらつ き具合を示しており, 光学的厚さの大小はそのまま飛行 高度に比例する. $\Delta \tau=0.15$ 付近が最もエラーバーが小さ い. 検証データから計算した值と観測で得られた $\mathrm{CO}_{2}$ の $\Delta \tau$ は良く対応しており，相関係数で0.99が得られた。観 測值と気象データの高度プロファイルを用いて推定した 地表からある高度までの気柱濃度はFig. 5のように得ら れた。下層付近で検証デー夕と比較して 5 ppmv近い差 が表れたが下層ほど $\mathrm{CO}_{2}$ 気柱量の減少傾向が確認でき る. 日中の強い日射の影響で植生による光合成の効果で $\mathrm{CO}_{2}$ 濃度が減少しているものと推測される. Fig.4で示し たエラーバーは受信望遠鏡の大口径化やレーザーパワー の高出力化により要求精度の達成が期待される。

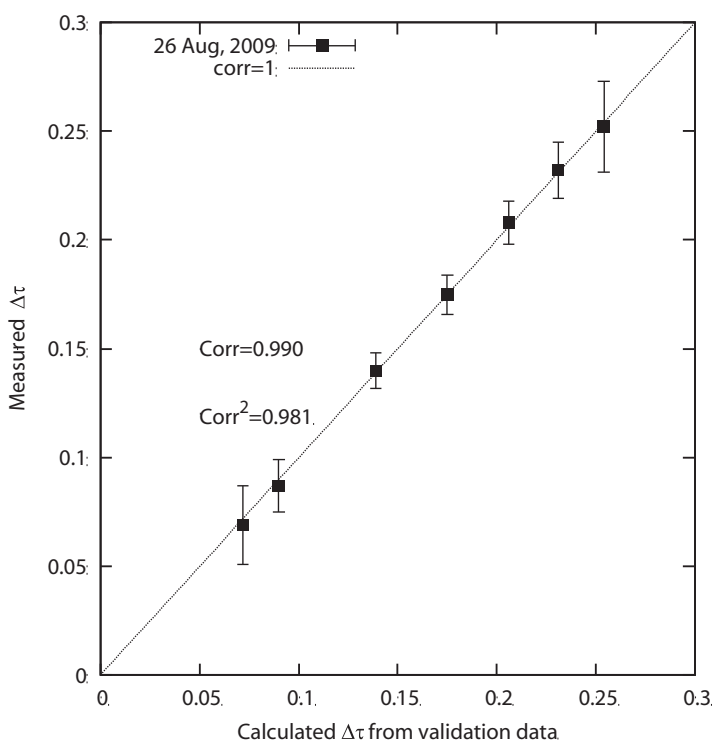

Fig. 4 Result of airborne flight tests: correlation between measured and calculated differential absorption optical depths from validation data.
現在この結果をもとに衛星搭載システムの仕様の策定 を開始している。実際には $\mathrm{CO}_{2}$ 単体の計測よりもミー散 乱ライダーや $\mathrm{CO}, \mathrm{CH}_{4}$ もくはイメージャ等, 他の要 素との同時観測が望ましい。今後の航空機観測では，人 為起源やバイオマス燃焼起源 $\mathrm{CO}_{2}$ の情報抽出に着目して 将来ミッションを前提とした継続観測を計画している.

\section{2 センサ技術への要求}

ライダーで利用される要素技術で特にレーザー開発は 衛星リソースの制限のために開発負荷が大きく，観測要 求を満たすために欠かせないセンサの心臓部となる。通 常のエアロゾル観測には沉用性の高いLD励起QswNd:YAGレーザーとその高調波が広く利用されている. HSRLや微量気体観測等で高精度の分光計測が求められ る場合, パルスレーザーの狭帯域化や発振波長を気体の 吸収線に安定化する機構が必要となる。DWLやDIAL, LASでは宇宙環境下にあってもこの機構が定常的に長期 間動作する設計が必要となる(例：狭帯域化率 > $99.9 \%$, 波長安定度 $100 \mathrm{kHz}$ 以下)。また上空からのレーザー照射 を考慮するとアイセーフ (eye safe)の観点から, $1570 \mathrm{~nm}$ や2060 nm帯のレーザーを用いてDWL，LASによる風， 微量気体観測用として利用が期待されている。他に宇宙 用センサとしてレーザー発振に重要となるのはLD励起 全固体レーザーの高出力化，および電気－光変換効率の 高効率化と発熱量の低減および冷却方法である. Nd:YAGレーザーのように8 85 m-LDを用いた励起構成 では基底準位から直接レーザー上準位へ励起できる分発 熱量が抑えられ, 冷却に要する電力の低減や, 熱レンズ 補償にかかる共振器設計の負荷の低減が期待できるため 当該技術の普及が望まれる。また打上げ時の衝撃や振 動, 過酷な環境下 (宇宙線, 熱サイクル, 超高真空)での 定常動作と高真空中で発生するアウトガスに起因する光
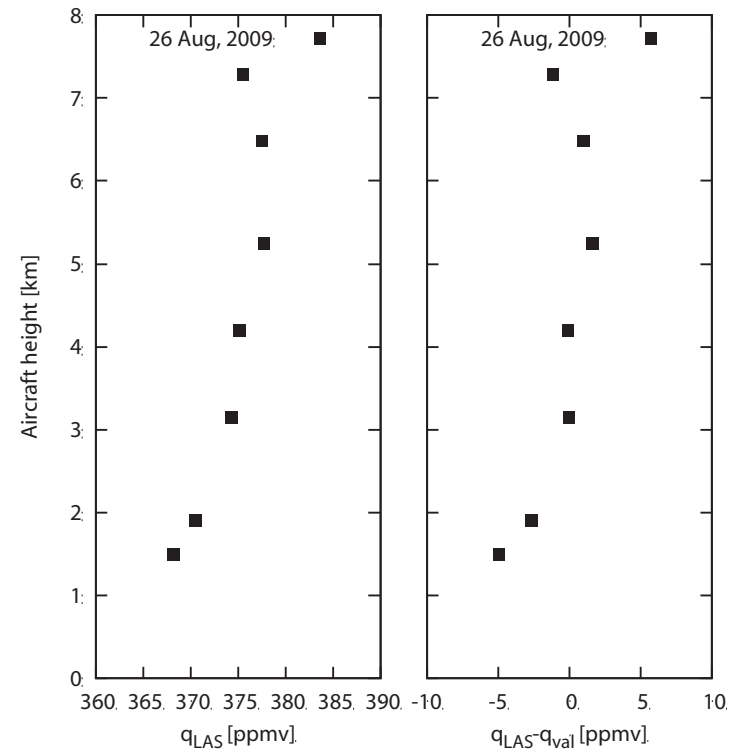

Fig. 5 Example of airborne test: evaluated partial columnaveraged column $\mathrm{CO}_{2}$ density $(=q)$ (left) and difference between calculated and measured values (right). $q_{\text {LAS }}$ is obtained from LAS, $q_{\text {val }}$ is obtained from validation data. 
学素子損傷のリスクヘッジが最も重要な要素となる.

検出器にはパルスレーザーの波形を歪みなく計測する ため最低でパルス線幅の3倍程度の帯域 $(300 \mathrm{MHz} \sim$ $1 \mathrm{GHz}$ )が求められる。広帯域の検出器では等価雑音が 増大し, 微弱なエコー検出に障害となる. 紫外〜可視波 長領域では光電子増倍管による光子計数法により高感度 な計測が可能となる。一方 $1.6 \mu \mathrm{m} \sim 2.0 \mu \mathrm{m}$ の波長は微量 気体の吸収線が比較的多く存在し，アイセーフ特性の レーザーが利用できCDWLやDIAL，LASに適した領域 である。ただし検出器の性能は可視域と比較して低雑音

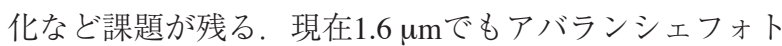
ダイオードや光電子増倍管を用いて光子計数法が可能と なったが，ダークカウントの低減とダイナミックレンジ の増大による性能の拡大が望まれる。

\section{5. おわりに}

望遠鏡の大口径, 軽量化やレーザーや周辺素子の技術 向上に伴って, 地上定点観測からネットワーク化, 車 載, 船舶, 航空機, 衛星と地球環境計測におけるほぼす ベてのプラットフォームでライダーの搭載が可能となっ た.これらのプラットフォームは物理量の動体解析に有 用なデー夕を供給し検証手段としても多様な場所で時間 変化を測定することができるようになった。エアロゾル の気候影響を評価するためCALIPSOが役立てられ， 2013年以降には後継機として日欧共同プロジェクトであ るEarthCAREの打ち上げが予定されている。 EarthCARE 搭載のライダーはレーダとの同時運用により, 地球の放 射収支を推定する研究に役立てられる。CALPSO, EarthCAREのその後の計画としてNASAの将来構想には 雲・エアロゾルと海洋エコシステムの観測を目的とした ACE (Aerosol/Cloud/Ecosystem) 計画 (2010年代中期以降の 打ち上げ目標)が挙げられている。 ACEには能動, 受動 型の観測器を5台搭載し，エアロゾルだけでなく雲粒子, 降雨までの総合的な観測を提案している。 また欧州宇宙 機関のADM-Aeolusにより，これまで実現されていな かった衛星からの大気風データの鉛直構造観測が期待さ れており，2013年の打上げが予定されている(2010年11 月時点). NASAの将来構想にも3D-Wind, SPARCLEと いった風観測計画が挙げられており, 気象予測の高度化 に向けた研究も進められている。また現在の地球観測衛 星は単一の観測器を搭載したものからACEのように受動 型と能動型を組合せた, 多機能型のシステムに移行しつ つある。初期段階においては各種観測デー夕間の利用や 有効性を焦点に研究がすすめられると思われるが, 今後 はこういった組合せによる衛星観測システムが長期モ二 タリングの中核を担うと想定される。JAXAにおいては 能動型観測器の最後の一角としてライダー搭載衛星に対 する議論が再始動し，基盤技術の早急な整備が求められ ている。レーザーや検出器についてはいずれの観測衛星 に対しても要求項目を満足するために高機能化や低電力 化，宇宙環境下を模擬した試験が急務である.
1) J. Bosenberg and R. Hoff: Plan for the implementation of the GAW Aerosol Lidar Observation Network GALION, WMO GAW Report No.178 (WMO Geneva, Switzerland 2008) p.52.

2) T. Nishizawa, H. Okamoto, T. Takemura, N. Sugimoto, I. Matsui, and A. Shimizu: J. Geopys. Res. 113 (2008) D21201.

3) A. Papayannis, V. Amiridis, L. Mona, G. Tsaknakis, D. Balis, J. Bosenberg, A. Chaikovski, F. De Tomasi, I. Grigorov, I. Mattis et al.: J. Geophys. Lett. 113 (2008) D10204.

4) M. Esselborn, M. Wirth, A. Fix, M. Tesche, and G. Ehret: Appl. Opt. 47 (2008) 346.

5) N. Cézard, A. Dolfi-Bouteyre, J.-P. Huignard, and P. H. Flamant: Appl. Opt. 48 (2009) 2321.

6) S. Kameyama, T. Ando, K. Asaka, Y. Hirano, and S. Wadaka: Appl. Opt. 46 (2007) 1953.

7) E. V. Browell, C. F. Butler, M. A. Fenn, W. B. Grant, S. Ismail, M R. Schoeberl, O. B. Toon, M. Loewenstein, and J. R. Podolske: Science 261 (1993) 1155.

8) H. Vogelmann and T. Trick: Appl. Opt. 47 (2008) 2116.

9) T. Fujii, T. Fukuchi, N. Cao, K. Nemoto, and N. Takeuchi: Appl. Opt. 41 (2002) 524.

10) M. Nakazato, T. Nagai, T. Sakai, and Y. Hirose: Appl. Opt. 46 (2007) 2269

11) G. J. Koch, J. Beyon, F. Gibert, B. W. Barnes, S. Ismail, M. Petros, P. Petzar, J. Yu, E. A. Modlin, K. J. Davis, and U. N. Singh: Appl. Opt. 47 (2008) 944.

12) F. Gibert, P. H. Flamant, and J. Cuesta: J. Atmos. Oceanic Technol. 25 (2008) 1477.

13) D. Sakaizawa, C. Nagasawa, T. Nagai, M. Abo, Y. Shibata, M. Nakazato, and T. Sakai: Appl. Opt. 48 (2009) 748.

14) C. E. Miller, D. Crisp, P. L. DeCola, S. C. Olsen, J. T. Randerson, A. M. Michalak, A. Alkhald, Rayner, D. J. Jacob, P. Suntharalingam et al: J. Geophys. Res. 112 (2007) D10314.

15) P. K. Parta, S. Maksyutov, Y. Sasano, H. Nakajima, G. Inoue, and T. Nakazawa: J. Geophys. Res. 108 (2003) 4759.

16) A. Kuze, H. Suto, M. Nakajima, and T. Hamasaki: Appl. Opt. 48 (2009) 6716.

17) S. Kameyama, M. Imaki, Y. Hirano, S. Ueno, S. Kawakami, D. Sakaizawa, and M. Nakajima: Opt. Lett. 34 (2009) 1513.

18) D. Sakaizawa, S. Kawakami, M. Nakajima, Y. Sawa, and H. Matsueda: J. Appl. Remote Sens. 3 (2010) 043548

19) A. Amediek, A. Fix, M. Wirth, and G. Ehret: Appl. Phys. B 92 (2008) 295.

20) J. B. Abshire, R. Haris, G. Allan, C. Weaver, J. Mao, X. Sun, W. Hasselbrack, S. R. Kawa, and S. Biraud: Tellus B 62 (2010) 770.

21) E. V. Browell, J. Dobler, S. Kooi, Y. Choi, F. W. Harrison, B. Moore, and T. S. Zaccheo: Proc. 25th Int. Laser Radar Conf., St. Peterburg Russia, July 2010.

22) D. M. Winker, R. H. Couch and M. P. McCormick: Proc. IEEE B 84 (1996) 164

23) J. B. Abshire, X. Sun, J. M. Sirota, J. F. McGarry, S. Palm, D. Yi, and P. Liiva: Geophys. Res. Lett. 32 (2005) L21S02.

24) D. M. Winker, W. H. Hunt, and J. McGill: Geophys. Res. Lett. 34 (2007) L17811.

25) M. A. Lefsky: Geophys. Res. Lett. 37 (2010) L15401.

26) I. Uno, K. Eguchi, K. Yumimoto, T. Takemura, A. Shimizu, M. Uematsu, Z. Liu, Z. Wang, Y. Hara, and N. Sugimoto: Nature Geoscience 2 (2009) 557.

27) T. Sakiyama, T. Y. Tanaka, A. Shimizu, and T. Miyoshi: Atmos. Chem. Phys. 10 (2010) 39.

28) T. Takemura, H. Okamoto, Y. Murayama, A. Numaguti, A. Higurashi, and T. Nakajima: J. Geophys. Res. 105 (2000) 17853.

29) A. Heliere, A. Lefebvre, T. Wehr, J.-L. Bezy, and Y. Durand: Proc. IGARSS 1 (2007) 4975.

30) European Space Agency: Earth Clouds, Aerosols and Radiation Explorer (ESA SP-1279 European Space Research and Technology Centre, 2004) p.66.

31) A. Ansmann, U. Wandinger, O. Le Rille, D. Lajas, and A. G. Straume: Appl. Opt. 46 (2007) 6606.

32) H. Kornich and E. Kallen: Tellus A 60 (2008) 261. 